\section{Editor-in-Chief \\ Barbara McLain - (retired Prof.) \\ University of Hawaii, USA}

The Israeli Journal of Aquaculture (IJA) is an interdisciplinary journal that is dedicated to sharing new research and tested applications of aquaculture

The IJA is devoted to scholarly articles for improved aquaculture practices and related industries

The IJA is a peer-reviewed, open-access, electronic journal

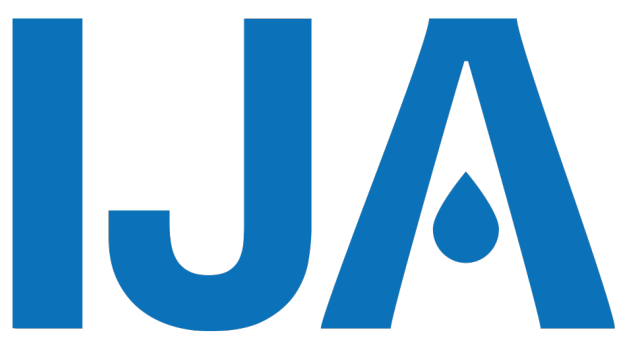

\section{The () Israeli Journal of Aquaculture}

An interdisciplinary online Open Access scientific journal

Published by the

\section{AquacultureHub}

A non-profit organization 501c3

http://www.aquaculturehub.org

in partnership with the

\section{University of Hawaii at Manoa} Library

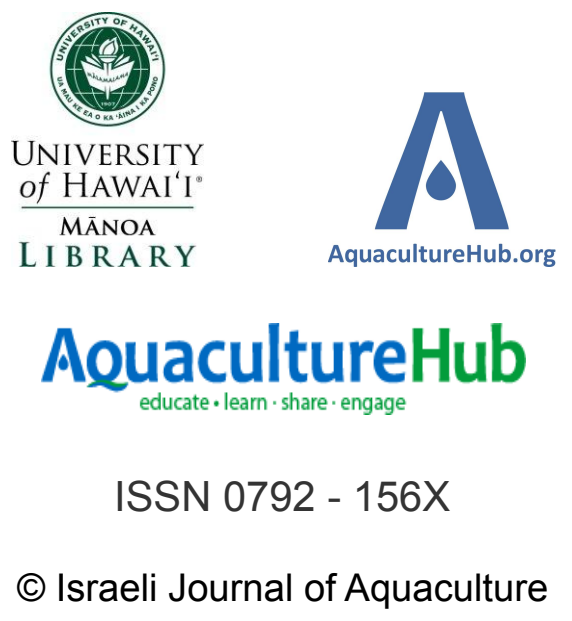


The Israeli Journal of Aquaculture - Bamidgeh, IJA_71.2019.1588, 9 pages

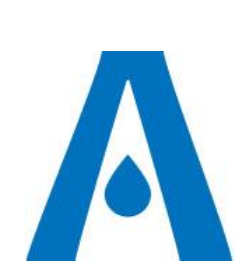

Produced by the AquacultureHub non-profit Foundation the IJA is an open-access, scientific journal, published on http://www.aquaculturehub.org/group/israelijournalofag uaculturebamidgehija

To read papers free of charge, please register online at the above website.

Sale of IJA papers is strictly forbidden.

\title{
Characteristics of Communities in the Extracts of Different Purple Soils in the Sichuan Basin, China
}

\author{
Tao He 1,2,\# , Xiang Chen ${ }^{1,2, \#, ~ R u i ~ J i a n g ~ 1,2, ~ Y a n l i ~ L i 1,2, ~ T i a n c a i ~ L i 1,2, ~}$ \\ Shengqi Su ${ }^{1,2 *}$
}

${ }^{1}$ College of Animal Science and Technology, Southwest University, Chongqing 400715, P. R. China
${ }^{2}$ Key Laboratory of Freshwater Fish Reproduction and Development (Ministry of Education)

Keywords: phytoplankton species; density; biomass; biodiversity; purple soil

\begin{abstract}
Pond soils play a fundamental role determining nutrient availability and regulate the characteristics of phytoplankton communities. This study investigated the change of phytoplankton communities in three types (alkaline, neutral, and acid) of purple soil. There were 107 species of phytoplankton detected in three purple soils belonging to 52 genera of 6 phyla (68 species in acid group, 69 species in neutral group and 64 species in alkaline group). The highest percentage of phytoplankton in three purple soil groups is Chlorophyta, followed by Bacillariophyta, and Euglenophyta. There were 23 species of 5 phyla in three purple soil ponds as the dominant species of phytoplankton, and the dominance varied from 0.05 to 0.67 . The dominant species in neutral and alkaline purple soil groups were more than those in acid purple soil. Phytoplankton density varied from 43 to $7360 \times 10^{6}$ ind/L in the acid purple soil group, and the ratio of the highest value to the lowest one was 170 . The variation range of phytoplankton density in neutral and alkaline purple soil ponds was 83 to $565 \times 10^{6}$ and 56 to $437 \times 10^{6} \mathrm{ind} / \mathrm{L}$, and the ratio of the highest value to the lowest one was 6.8 and 7.8 respectively. The variation of biodiversity indices (Shannon-Wiener index, Pielous evenness index and Margalef richness index), were higher in the acid purple soil group than in the neutral and alkaline purple soil groups, similar to the result of phytoplankton density. Our results indicate that the phytoplankton community was more stable in the neutral and alkaline purple soil groups than in the acid soil group, and these two soil types are recommended for site-selection to build aquaculture ponds.
\end{abstract}

* Corresponding author. Corresponding author: Tel: +86 2368250202; email:

sushengqi@swu.edu.cn

\#These authors contributed equally. 


\section{Introduction}

The fish yield in aquaculture ponds usually varies remarkably even when same culture methods and technology are used (Wudtisin and Boyd, 2006). One fundamental factor that has been overlooked is the type of pond soils. The chemical property of soil types is critical to determine the water quality in fish ponds. Sichuan Basin is a low land region in southwestern China with an expansion of $229,500 \mathrm{~km}^{2}$ surrounded by upland regions and mountains. The basin's soils are largely exposed to red sandstone leading to the nickname Purple Soil Basin in China (Zhang et al., 2011). The soils in the area are divided into 10 types based on fertility characters with six main types, namely alluvial, purple, yellow, red, mountain brown, and alpine frozen desert soils. Purple soil is the dominant soil in the Sichuan Basin, while the yellow soil and red soil are common at lower elevations (Fu et al., 2015). In the Sichuan Basin, many ponds have been built for aquaculture, but the impact of soil types on the composition of phytoplankton community has not been studied.

In China, most carp species in aquaculture, planktivorous, and fish production in fertilized ponds, and are positively correlated with phytoplankton productivity (Boyd, 1998). In addition, the potential fish production in ponds increases with increasing availability of N, P, and K in the soil (Banerjea 1967). Therefore, it is possible to apply the method used in agronomy to determine the relationship between the nutrients available in pond soil and primary productivity in pond water. The amount of fertilizer needed should be related to soil types to achieve a high level of primary productivity, leading to high fish production in ponds (Banerjee et al., 2009).

Phytoplankton is a very diverse group of aquatic organisms and plays an important role in aquatic ecosystems (Egorov et al., 2018). Regardless of the type of water body, phytoplankton is the basic primary producer, and directly or indirectly provides food to fish. The abundance and composition of phytoplankton is indicative of productive status between oligotrophic and eutrophic waters. The main focus of current literature is on the relationship of phytoplankton abundance with nutrients in water, but few studies have examined its abundance and composition in relation to soil types (Siddika et al., 2012).

The temporal fluctuation of phytoplankton in ponds varies with physiochemical conditions in the environment (Allende and Mataloni, 2013). The texture of the pond soil and ion exchange processes at the soil-water interface are important determinants for the health and growth of fish or shrimp in ponds. Nutrients and organic residues tend to accumulate at the bottom and will not return to the water phase unless water mass turnover occurs due to wind action. The pond bottom soil and the accumulated sediments are integral parts of ponds. Concentrations of nutrients, organic matter, and microorganism density at the base of the pond are several orders of magnitude greater than in the water and these storages determine the potential of a pond to support fish growth and production (Avnimelech, 2003).

In the present study, we aim to investigate the impact of three soil types on the size, distribution, and biodiversity of phytoplankton, and explore the relationship between phytoplankton dynamics and pond soil types. The results of this study should provide useful information for choosing soil types for site selection to build fish ponds.

\section{Material and Methods}

Soil collection

Soil samples were collected at Hejiang (S1), Beibei (S2), and Tongnan (S3) respectively, located in the southwest of China from March to April 2016 (Table 1, S1). At each sampling location, $100 \mathrm{~kg}$ soil was collected from 5-8 randomly selected quadrate points.

After the soil samples were brought to the laboratory, they were spread onto a plain thin layer of plastic sheeting and air-dried at room temperature $\left(22-28^{\circ} \mathrm{C}\right)$. After non-soil components such as stones and plant residues had been removed via manual screening, the samples were ground and filtered using a $2-\mathrm{cm}$ aperture sieve. All samples were sealed and stored for further use (Carter and Gregorich, 2008). 
Table 1. Sample information of the tested soil

\begin{tabular}{|c|c|c|c|c|}
\hline Sample & Type & $p H$ & location & GPS \\
\hline S1 & Acid purple & 4.77 & Hejiang, Sichuan & $\begin{array}{l}\mathrm{E} 106^{\circ} 0^{\prime} 31^{\prime \prime}, \\
\mathrm{N} 28^{\circ} 52^{\prime} 17^{\prime \prime}\end{array}$ \\
\hline $\mathrm{S} 2$ & Neutral purple & 7.46 & Beibei, Chongqing & $\begin{array}{l}\mathrm{E} 106^{\circ} 24^{\prime} 52^{\prime \prime}, \\
\mathrm{N} 29^{\circ} 48^{\prime} 44^{\prime \prime}\end{array}$ \\
\hline S3 & Alkaline purple & 7.92 & Tongnan, Chongqing & $\begin{array}{l}\mathrm{E} 105^{\circ} 52^{\prime} 10^{\prime \prime}, \\
\mathrm{N} 29^{\circ} 51^{\prime} 31^{\prime \prime}\end{array}$ \\
\hline
\end{tabular}

Experimental design

The experiment was conducted in the Southwest University from April to September 2016. The three types of purple soil $(50 \mathrm{~kg})$ were placed in the acrylic cylinders (Radius: $40 \mathrm{~cm}$; Height: $80 \mathrm{~cm}$ ) respectively, and there were three replicates of each soil group. All the cylinders were arranged evenly in a large and bright sunlight shed. The testing water was prepared with the volume ratio of soil to water at 1:5 (Nimrat et al., 2008), in which the soil layer in the cylinder, was $12-\mathrm{cm}$ thick and the water depth was $60 \mathrm{~cm}$. According to the stocking density in commercial fish ponds, seven Xiangyun crucian carp (total length $7.0 \pm 0.1 \mathrm{~cm}$, weight $9.6 \pm 0.1 \mathrm{~g}$ ) were stocked in each cylinder, fed with formulated feed $(34.0 \%$ crude protein, $3.0 \%$ crude fat) at a daily ration of $3 \%$ body weight at 08:30 and 17:30 for 150 days. The water was topped up to compensate the loss due to evaporation.

Water samples (1L) were collected from each tank every 30 days, then fixed with Lugo's solution. After settling for over 24 hours, samples were concentrated for phytoplankton identification and quantification (Hu and Wei, 2006; Deng, 2012).

Data analysis

Phytoplankton density: $\mathrm{N}=(\mathrm{Cs} \times \mathrm{V}) /(\mathrm{Fs} \times \mathrm{Fn} \times \mathrm{U}) \times \mathrm{Pn}$.

$\mathrm{N}$ is the number of phytoplankton cells per unit volume (cells / L).

Cs is the counting frame area. Fs is the visual field area of the microscope.

$\mathrm{Fn}$ is the visual field area for the counting. $\mathrm{V}$ is the volume $(\mathrm{ml})$ for quantitative analysis after

$1 \mathrm{~L}$ sample concentrated.

$U$ is the volume of the counting frame.

$\mathrm{Pn}$ is the number of phytoplankton by counting.

The biomass of phytoplankton was converted by volume method. The algae volume was calculated by the geometric volume formula with similar shape, and the average wet weight was calculated according to $10^{9} \mu \mathrm{m}^{3}=1 \mathrm{mg}$.

Phytoplankton dominance analysis: $Y=f_{i} \times P_{i}$.

$Y$ is the dominance of different species. $Y \geq 0.05$ is the dominant species.

$f_{i}$ is the frequency of $i$ species appearing at the same sampling time and duplicate.

$\mathrm{Pi}$ is the proportion of $\mathrm{i}$ species cells in the three cylinders.

Phytoplankton diversity was estimated using the Shannon-Wiener diversity index $\left(\mathrm{H}^{\prime}\right)$, Pielous evenness index ( $\left.\mathrm{J}^{\prime}\right)$ and Margalef richness index (D) (Shen, 1990; Alhassan,

$$
\mathrm{H}^{\prime}=-\sum_{1}^{\mathrm{s}}\left(\mathrm{n}_{\mathrm{i}} / \mathrm{N}\right) \bullet \log _{2}\left(\mathrm{n}_{\mathrm{i}} / \mathrm{N}\right)
$$

2015).

$\mathrm{H}^{\prime}$ is the diversity index.

$\mathrm{N}$ is the total number of individuals.

$\mathrm{ni}$ is the total number of $\mathrm{i}$ species.

$$
\mathbf{J}^{\prime}=\mathbf{H}^{\prime} / \log _{2} \mathbf{S}
$$

$J^{\prime}$ is the evenness index.

$\mathrm{H}^{\prime}$ is the diversity index.

$\mathrm{S}$ is the total number of species.

$$
\mathrm{D}=\frac{\mathrm{S}-1}{\log _{2} \mathrm{~N}}
$$

$D$ is the richness index.

$\mathrm{S}$ is the total number of species.

$\mathrm{N}$ is the total number of individuals. 
The software SPSS 17.0 was used for statistical analysis. One-way analysis of variance (one-way ANOVA) with Duncan's multiple comparison tests was applied to test differences in each nutrient, in the cell densities, and in the biomass of different soil extract. A significance level of $0.05 \%$ was used in the analysis.

\section{Results}

Phytoplankton species in different purple soil groups

There were 107 species of phytoplankton detected in three purple soil ponds belonging to 52 genus of 6 phyla (68 species in acid group, 69 species in neutral group and 64 species in alkaline group). All algae were composed of 52 species of Chlorophyta, 23 species of Bacillariophyta, 17 species of Euglenophyta, 7 species of Cyanophyta, 4 species of Pyrrophyta, and 4 species of Cryptophyta, (S2, Table 2). The highest percentage of phytoplankton in three purple soil ponds is Chlorophyta, followed by Bacillariophyta, and Euglenophyta. Chlorophyta, Bacillariophyta, and Euglenophyta accounted for $49 \%, 19 \%$, and $15 \%$ in the acid purple soil group; $52 \%, 22 \%$, and $11 \%$ in the neutral soil group; $45 \%, 22 \%$, and $14 \%$ in the alkaline group, respectively.

Table 2. Phytoplankton species in different purple soil groups

\begin{tabular}{lllll}
\hline Species & Sample & & & \\
\hline & S1 & S2 & S3 & Sum \\
\hline Chlorophyta & 34 & 38 & 29 & 23 \\
Bacillariophyta & 12 & 13 & 14 & 17 \\
Euglenophyta & 10 & 8 & 9 & 7 \\
Cyanophyta & 6 & 4 & 5 & 4 \\
Pyrrophyta & 3 & 4 & 3 & 4 \\
Cryptophyta & 3 & 2 & 4 & 107 \\
\hline Sum & 68 & 69 & 64 & \\
\hline
\end{tabular}

There were 23 species of 5 phyla in three purple soil ponds as the dominant species of phytoplankton, and the dominance varied from 0.05 to 0.67 (Table 3 ). In the previous 60 days, Chlorophyta were the dominant species in acidic and neutral purple soil ponds, while Chlorophyta and Cryptophyta were dominant in alkaline purple soil groups. After 90 days, the dominant species were Chlorophyta and Cyanophyta in acid purple soil pond. Chlorophyta, Pyrrophyta, and Euglenophyta were dominant in the neutral and alkaline purple soil groups. The dominant species in neutral and alkaline purple soil groups were more than the ones in acid purple soil, which indicated that the phytoplankton diversity in neutral and alkaline purple soil was higher than the diversity in the acid group. 
Table 3. The dominant species and dominance of phytoplankton in different purple soil ponds

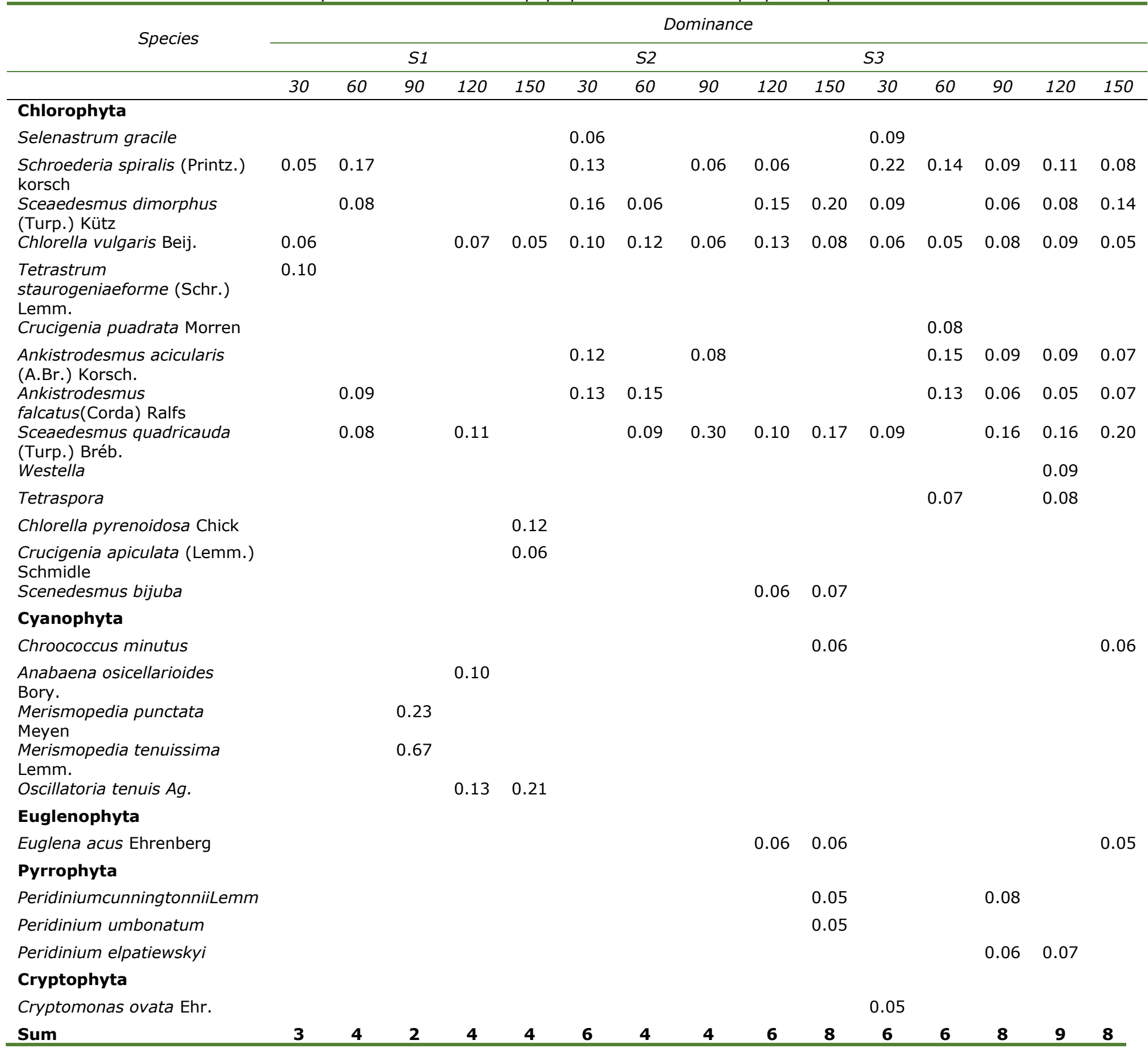

\section{Variation of phytoplankton density and biomass}

Fig. 1 shows the variation of phytoplankton density in the three purple soil groups. The phytoplankton density increased continuously up to 90 days in acid and neutral purple soil groups, while it increased up to 120 days in the alkaline purple soil group, and then decreased. Phytoplankton density varied from $43 \times 10^{6}$ to $7360 \times 10^{6} \mathrm{cells} / \mathrm{L}$ in acid purple soil group, from $83 \times 10^{6}$ to $565 \times 10^{6}$ cells/L in neutral purple soil group, and from $56 \times 10^{6}$ to $437 \times 10^{6}$ cells/L in alkaline purple soil group. 


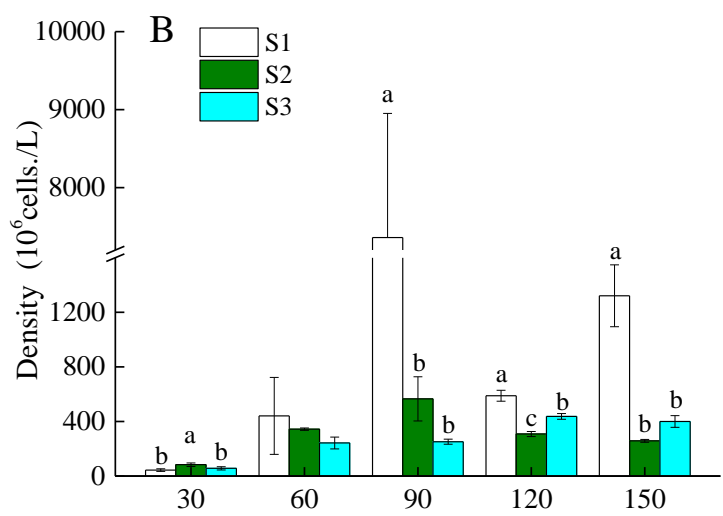

Fig.1 Variation of Phytoplankton Density in Different Purple Soil Groups

The biomass of phytoplankton increased with the culture time in three purple soil ponds (Fig. 2). The variation range of phytoplankton biomass was between 7.5 and 119.2 $\mathrm{mg} / \mathrm{L}$ in acid purple soil group, from 10.1 to $81.8 \mathrm{mg} / \mathrm{L}$ in neutral purple soil group, and from 8.8 to $123.9 \mathrm{mg} / \mathrm{L}$ in alkaline purple soil group. The biomass of phytoplankton in acid purple soil ponds was lower than that in neutral purple soil groups before 90 days, but it was higher than in neutral and alkaline purple soil ponds after 90 days.

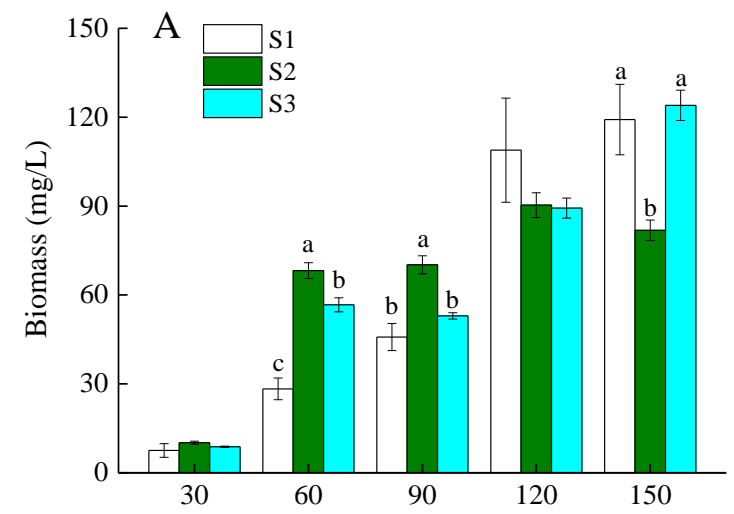

Fig.2. Variation of Phytoplankton Biomass in Different Purple Soil Groups

Variation of phytoplankton diversity in different purple soil groups

Phytoplankton community structure was reflected by the diversity index. In this study, the Shannon-Wiener diversity index varied from 1.56 to 4.25 in acid purple soil group, which was the lowest value in 90 days and the highest in 120 days. The variation range of Shannon-Wiener diversity index in neutral purple soil group was 2.37 to 4.10, which was the lowest in 90 days and the highest in 60 days. The Shannon-Wiener diversity index varied from 2.07 to 3.95 in alkaline purple soil group, which was the lowest value in 90 days and the highest in 60 days (Table 4 ).

The variation range of Pielou's evenness index in acid purple soil ponds was 0.34 to 0.81 , which was the lowest at 90 days and the highest at 60 days, while the Pielou's index varied from 0.67 to 0.90 in neutral purple soil group, the lowest at 90 days and the highest at 120 days. The variation range of Pielou's index in the alkaline purple soil group was 0.80 to 0.88 (Table 4 ).

The Margalef richness index varied from 1.59 to 3.49 in acid purple soil ponds, which was lowest at 90 days, and highest at 30 days, while the index in neutral purple soil ponds varied from 1.90 to 3.11 , to the lowest at 150 days and to the highest at 60 days. The variation range of Margalef index in alkaline purple soil ponds was 1.90 to 2.97 with the lowest value at 30 days and the highest at 60 days (Table 4). 
Table 4 Phytoplankton diversity index in three purple soil groups

\begin{tabular}{|c|c|c|c|c|c|c|c|c|c|c|c|c|c|c|c|c|}
\hline \multicolumn{7}{|c|}{ Shannon-Wiener index } & \multicolumn{4}{|c|}{ Pielou's index } & \multicolumn{6}{|c|}{ Margalef index } \\
\hline \multirow{2}{*}{\multicolumn{2}{|c|}{ Sample }} & \multicolumn{15}{|c|}{ Days } \\
\hline & & 30 & 60 & 90 & 120 & 150 & 30 & 60 & 90 & 120 & 150 & 30 & 60 & 90 & 120 & 150 \\
\hline $\mathrm{S} 1$ & 3.6 & & 3.87 & 1.56 & 4.25 & $\begin{array}{l}3.5 \\
5\end{array}$ & 0.68 & 0.81 & 0.34 & $\begin{array}{l}0.8 \\
7\end{array}$ & $\begin{array}{l}0.7 \\
6\end{array}$ & 3.49 & $\begin{array}{l}2.4 \\
7\end{array}$ & $\begin{array}{l}1.5 \\
9\end{array}$ & 2.63 & 2.12 \\
\hline $\mathrm{S} 2$ & 3.6 & & 4.10 & 2.37 & 4.00 & $\begin{array}{l}3.7 \\
2\end{array}$ & 0.80 & 0.81 & 0.67 & $\begin{array}{l}0.9 \\
0\end{array}$ & $\begin{array}{l}0.8 \\
8\end{array}$ & 2.07 & $\begin{array}{l}3.1 \\
1\end{array}$ & $\begin{array}{l}2.7 \\
4\end{array}$ & 2.16 & 1.90 \\
\hline S3 & 3.7 & & 3.95 & 2.07 & 3.87 & $\begin{array}{l}3.9 \\
0\end{array}$ & 0.85 & 0.80 & 0.88 & $\begin{array}{l}0.8 \\
4\end{array}$ & $\begin{array}{l}0.8 \\
2\end{array}$ & 1.90 & $\begin{array}{l}2.9 \\
7\end{array}$ & $\begin{array}{l}2.3 \\
7\end{array}$ & 2.25 & 2.58 \\
\hline
\end{tabular}

\section{Discussion}

After soil flooding, algae in the soil will germinate, proliferate in aquaculture water under suitable conditions, and become an important source of phytoplankton for zooplankton and fish (Katri et al., 2009; Li et al., 2012; Zou et al., 2017). At the same time, the material exchange process at the interface between soil and water after soil flooding, will affect the physical-chemical properties of water (Nabila et al., 2012; Yang et al., 2017), and the composition and community structure of phytoplankton species (Tang et al., 2014). Consequently, there are significant differences in the composition, properties, and nutrient content of algae among different types of soils (Zhang, 1988; He, 2003), which may cause the differences of phytoplankton community-structure in aquaculture ponds based on different soils. Soil condition, especially the soil $\mathrm{pH}$, has a great influence on the water quality, which affects aquaculture production (Boyd, 2003). Acid-alkaline level of pond water is the primary factor influencing the phytoplankton community (species, biomass, density and cell diameter), as different kinds of phytoplankton have their optimum acid-alkaline levels (Beauchamp and Kerekes, 1989; Sui et al., 2016). Similarly, the phytoplankton community, which is the key indicator of ecosystem stability (Zhou et al., 2018), showed different characteristics in different types of purple soil in this study.

Suitable environmental conditions vary remarkably among different phytoplankton species (Guo et al., 2014). In general, Chlorophyta were the dominant species in aquaculture ponds (Li et al., 2015). With time, Cyanophyta increased and became the dominant specie, which caused water eutrophication (Tang et al., 2014). In this study, Chlorophyta were the dominant species in the three purple soil groups at the beginning of culture. In the middle and late stage of culture, Cyanophyta were dominant in the acid purple soil group, while the dominant species in neutral and alkaline purple soil groups were Chlorophyta, Pyrrophyta, and Euglenophyta. The different results could be caused by the different physicochemical properties of the culture water (Eviner, 1997), as the levels of phosphorus and calcium in neutral and alkaline purple soil groups were higher than the ones in acid purple soil group (Benfield, 1986).

High phytoplankton biomass often results from the hyper-eutrophic pond conditions or high fish densities (Paul et al., 2001). In this study, the biomass and density of phytoplankton increased with the culture process in three purple soil ponds. Tang et al. (2014) considered that the ratio of the highest to the lowest of phytoplankton density could reflect the stability of phytoplankton community structures. In the present study, the phytoplankton density varied from 43 to $7360 \times 10^{6}$ ind. / $\mathrm{L}$ in the acid purple soil group, and the ratio of the highest value to the lowest one was 170 . The variation range of phytoplankton density in neutral and alkaline purple soil ponds was 83 to $565 \times 10^{6}$ and 56 to $437 \times 10^{6}$ ind. / L, and the ratio of the highest value to the lowest one was 6.8 and 7.8 respectively. As the phytoplankton density varied less, the results showed that the phytoplankton community structure in the neutral and alkaline purple soil ponds was more stable than that in the acid purple soil ponds.

Phytoplankton diversity (Shannon-Wiener index, Pielou's evenness index and Margalef richness index) reflects the distribution, evenness, and dominance of algae species at a particular site. A relatively lower diversity value indicates that some of the species which have a competitive advantage in the specific environment become dominant, resulting in the decrease of species evenness, and decreasing the diversity 
value (Sui et al., 2016). In the present study, the variation range of three biodiversity indices was wider in the acid purple soil group than in the neutral and alkaline purple soil groups, which indicated that the phytoplankton community was more stable in the neutral and alkaline purple soil groups than in the acid soil group similar with the result of phytoplankton density. Further investigation needs to be conducted on the difference of phytoplankton diversity between neutral purple soil group and alkaline soil group.

\section{Acknowledgements}

The present research was financially supported by National Natural Science Foundation of China (No. 31472311) and Chongqing Research Program of Basic Research and Frontier Technology (No. cstc2016jcyjA0327).

\section{References}

Alhassan E., 2015. Seasonal variations in phytoplankton diversity in the bui dam area of the Black Volta in Ghana during the pre- and post-impoundment periods. Rev Biol Trop, 63(1): 13.

Allende L., and G. Mataloni, 2013. Short-term analysis of the phytoplankton structure and dynamics in two ponds with distinct trophic states from cierva point (maritime antarctica). Polar Biol, 36(5): 629-644.

Avnimelech Y., 2003. Shrimp and fish pond soils: Processes and management. Aquaculture, 220(1-4): 549-567.

Banerjee A., Chattopadhyay G. and C. Boyd, 2009. Determination of critical limits of soil nutrients for use in optimizing fertilizer rates for fish ponds in red, lateritic soil zones. Aquacult Eng, 40(3): 144-148.

Beauchamp S. and J. Kerekes, 1989. Effects of acidity and doc on phytoplankton community structure and production in three acid lakes (nova scotia). Water Air Soil Poll, 46(1-4): 323-333.

Benfield J., 1986. Vascular plant breakdown in fresh-water ecosystems. Annu Rev Ecol Evol S, 17(17): 567-594.

Boyd C., 2003. Bottom soil and water quality management in shrimp ponds. J Appl Ichthyol, 13(1-2): 11-33.

Boyd C., 1998. Pond aquaculture water quality management. Boston, Massachusetts, USA: Kluwer Academic Publishers.

Carter M. and E. Gregorich, 2008. Soil sampling and methods of analysis second edition. Canada: Canadian Society of Soil Science.

Deng J, 2012. A map of common algae in inland waters of china. Wuhan: Yangtze River Press.

Egorov N., Krupnova T., Mashkova I. and A. Kostryukova, 2018. Phytoplankton biodiversity and its relationship with aquatic environmental factors in Lake Uvildy, South Urals, Russia. Biodiversitas, 19(4): 1422-1428.

Eviner V., 1997. Plant-microbial interactions. Nature, 385(6611): 26-27.

Fu M., Wang W., Qin J., Lu H., Yao W. and S. Su, 2015. Growth response of phytoplankton to different soil extracts for choosing suitable soil types for pond aquaculture. Bangl J Bot, 44(5): 787-796.

Guo S., Feng Y., Wang L., Dai M., Liu Z., Bai Y. and J. Sun, 2014. Seasonal variation in the phytoplankton community of a continental-shelf sea: the east china sea. Mar Ecol Prog Ser, 516(12): 103-126.

He Y., 2003. Purple soils in china (2). Bei Jing: Science Press.

Hu H. and Y. Wei, 2006. The freshwater algae in china-systematics, taxonomy and ecology. Beijing: Science Press.

Katri A., Kaarina C., Paulin L., Suomalainen S., Tuomi P. and J. Rapala, 2009. High diversity of cultivable heterotrophic bacteria in association with cyanobacterial water blooms. Isme J, 3(3): 314-325.

Li G., Dong J., Li D., Bao G. and Y. Liu, 2012. Effects of enhanced temperature on algae cells recruitment from sediment and their physiological characteristics. Acta Hydrobiol Sini, 36(4): 696-703. 
Li X., Tao L., Zhang S., Zhao X., Lu G. and G. Li, 2015. The effects of a new ceramsite ecological floating bed on the water quality and phytoplankton in grass carp culture ponds. Acta Hydrobiol Sini, 39(3): 507-516.

Nabila G., Alain B., Lisa P., Martine R., Langlade M., Joel O. and L. Charpy, 2012. Nutrient fluxes between water column and sediments: Potential influence of the pearl oyster culture. Mar Pollut Bull, 65(10-12): 500-505.

Nimrat S., Suksawat S., Maleeweach P. and V. Vuthiphandchai, 2008. Effect of different shrimp pond bottom soil treatments on the change of physical characteristics and pathogenic bacteria in pond bottom soil. Aquaculture, 285(1-4): 123-129.

Paul V., Zimba C., Christopher P. and R. Weirich, 2001. Phytoplankton community structure, biomass, and off-flavor pond size relationships in Louisiana catfish ponds. J World Aquacult Soc, 32(1): 96-104.

Shen Y., 1990. New microbiological monitoring technology. Beijing: China Building Industry Press.

Siddika F., Shahjahan M. and M. Rahman, 2012. Abundance of plankton population densities in relation to bottom soil textural types in aquaculture ponds. Inter $\mathrm{J}$ Agricult Res, Innov Tech, 2(1): 56-61.

Sui F., Zang S., Fan Y. and H. Ye, 2016. Effects of different saline-alkaline conditions on the characteristics of phytoplankton communities in the lakes of songnen plain, china. PLoS One, 11(10): 1-18.

Tang J., Wang Y., Dai Y. and T. Zhou, 2014. Effects of three fertilization methods on phytoplankton community in integrated culture of freshwater pearl mussel (Hyriopsis cumingii) and fishes. J Fish China, 38(9): 1421-1430.

Wudtisin I. and C. Boyd, 2006. Physical and chemical characteristics of sediments in catfish, freshwater prawn and carp ponds in Thailand. Aquac Res, 37(12): 1202-1214.

Yang P., Jin B., Tan L. and C. Tong, 2017. Temporal variation of nutrients fluxes across the sediment-water interface of shrimp ponds and influencing factors in the Jiulong river estuary. Acta Ecol Sini, 37(1): 192-203.

Zhang C., 1988. Distribution of algae in different stages of primitive soil-forming process. Chinese J Soil Sci, (4): 184-186.

Zhang W., Wei C., Li Y., Wang G. and D. Xie, 2011. Effects of rock fragments on infiltration and evaporation in hilly purple soils of Sichuan basin, China. Environ Earth Sci, 62(8): 1655-1665.

Zhou Y., Hu B., Zhao W., Cui D., Tan L. and J. Wang, 2018. Effects of increasing nutrient disturbances on phytoplankton community structure and biodiversity in two tropical seas. Mar Pollut Bull, 135: 239-248.

Zou W., Wang Z., Song Q., Luo Y., Liu L. and P. Yang, 2017. Regulation of two benthic bacteria on the recruitment of dormant microcystis aeruginosa in upper sediment. Acta Sci Circumst, 37(11): 4160-4169. 